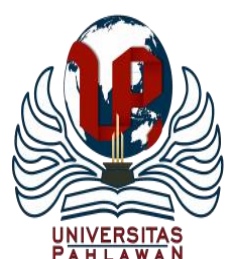

Jurnal Abdidas Volume 2 Nomor 6 Tahun 2021 Halaman 1356 - 1361

JURNAL ABDIDAS

http://abdidas.org/index.php/abdidas

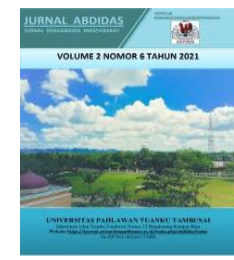

\title{
Penyuluhan Dan Pelatihan Bantuan Hidup Dasar(BHD) Kecamatan Mapili Kabupaten Polewali Mandar
}

\author{
Idawati Ambohamsah ${ }^{1 凶}$, Farmin $_{\mathrm{Arfa}^{2}}{ }^{2}$ Rahmadani Tanjung ${ }^{3}$ \\ Keperawatan, Akademi keperawatan YPPP Wonomulyo, Indonesia ${ }^{1,2,3}$ \\ E-mail : Idawatiambohamsah87@gmail.com ${ }^{1}$ Farminarfan86@ gmail.com $^{2}$ \\ Rahmadanitanjung37@gmail.com ${ }^{3}$
}

\begin{abstract}
Abstrak
Bantuan hidup dasar merupakan serangkaian usaha awal untuk mengembalikan fungsi pernapasan dan sirkulasi pada seseorang yang mengalami henti nafas dan henti jantung. Pemberian pengetauan bantuan hidup dasar ini membuat masyarakat dapat mengindetifikasi tanda-tanda korban yang membutuhkan pertolongan pertama, mengetaui cara melakukan bantuan hidup dasar yang benar dan tepat. Kondisi kegawatdaruratan ini dapat terjadi dimana saja, kapan saja. Oleh karena itu, untuk meningkatkan pengetahuan mengenai bantuan hidup dasar dilakukan penyuluhan dan pelatihan pada masyarakat. Tujuan kegiatan pengabdian ini adalah untuk meningkatkan pemahaman dan keterampilan sasaran dalam memahami serta menerapkan pelaksanaan tatalaksana bantuan hidup dasar serta mengaplikasikannya. Metode yang digunakan adalah ceramah, diskusi dan demonstrasi. Kegiatan ini dilakukan di Desa Rumpa Kecamatan Mapili pada tanggal 10 September 2020 dengan jumlah sampel 20 responden. Dilaksanakan dalam tiga tahapan yaitu persiapan,pelaksanaan dan evaluasi. Hasil evaluasi menunjukan bahwa sebelum penyuluhanhanya 4 responden (20\%) mengetahuai dan memberikan pertolongan pertama,setelah dilakukannya penyuluhan sebanyak 15 responden (75\%) masyarakat mampu mengetahui dan memberikan dan memberikan pertolongan pertama pada korban henti nafas dan jantung.dan juga masyarakat lebih percaya diri untuk senantiasa memberikan pertolongan pertama pada korban henti nafas dan jantung.
\end{abstract}

Kata kunci: penyuluhan, pelatihan, bantuan hidup dasar

\begin{abstract}
Basic life support is a series of initial efforts to restore respiratory and circulation functions in someone who has stopped breathing and cardiac arrest. The provision of knowledge of basic life support allows the public to identify signs of victims who need first aid and know how to perform basic life support correctly and appropriately. This emergency condition can occur anywhere at any time,therefore to increase knowledge about basic life support,counseling and training are carried out to the community. Is a discucssion lecture and demontration of this activity carried out in the village of Rumpa,Mapili disctrict on September 10 2020 with a sample of 20 respondents. It is carried out in there stages, namely preparation for implementation and evaluation the evaluation results showed that before counseling only 4 respondents(20\%) knew and proviied first aid after counseling as many as 15 respondents(75\%) the community was able to know and provide and provide first aid to victims of respiratory and cardiac arrest and also people were more confident to always provide first aid to victims of respiratory and cardiac arrest.
\end{abstract}

Keywords: basic life support,training,counseling

Copyright (c) 2021 Idawati Ambohamsah, Farmin Arfa, Rahmadani Tanjung

$\triangle$ Corresponding author

Address : Akademi keperawatan YPPP Wonomulyo

Email : idawatiambohamsah87@gmail.com

DOI : https://doi.org/10.31004/abdidas.v2i6.481

ISSN 2721- 9224 (Media Cetak)

ISSN 2721- 9216 (Media Online) 
1357 Penyuluhan Dan Pelatihan Bantuan Hidup Dasar(BHD) Kecamatan Mapili Kabupaten Polewali Mandar - Idawati Ambohamsah, Farmin Arfa, Rahmadani Tanjung

DOI: https://doi.org/10.31004/abdidas.v2i6.481

\section{PENDAHULUAN}

Bantuan Hidup Dasar serangkaian usaha awal untuk mengembalikan fungsi pernafasan dan sirkulasi pada seseorang yang mengalami henti nafas dan henti jantung.terdapat 2 unsur yaitu penyelamatan pernafasan,kompresi dada. Istilah bantuan hidup dasar ini juga biasa dikenal dengan RJP (Suranadi 2017). Indonesia merupakan salah satu negara yang berada diwilayah yang rawan terhadap berbagai bencana alam(factor alam atau non alam).Indonesia mengalami tingkat kematian tertinggi yang disebabkan oleh kecelakaan lalu lintas, tidak luput dari ikut faktor bencana juga mempengaruhi tingkat kematian di Indonesia (Pengabdian, Pengusul 2018).

Proyeksi yang dilakukan WHO kematian akibat kecelakaan lalulintas menurun $30 \%$ dinegara-negara yang berpendapatan tinggi, sedangkan negara-negara yang rendah dan negara berkembang seperti Indonesia dan Vietnam mengalami peningkatan (Sawiji 2018). Berdasarkan data yang dicatat,jumlah korban yang tewas akibat kecelakaan pada tahun 201729.810 sedangkan pada tahun 2018 mengalami peningkatan yaitu 103.672 kasus. Di Kabupaten Polewali mandar kasus kecelakaan lalu lintas mengalami peningkatan setiap tahunannya. Pada tahun 2018 terdapat 256 kasus kecelakaan lalulintas yang terjadi. Sedangkan Badan Nasional Penanggulangan Bencana (BNPB) mencatat, sebanyak 1.212 bencana alam telah terjadi selama 2020 di Polewali Mandar.Banjir menjadi bencana terbanyak,disusul angin puting beliung dan tanah longsor. Hal ini terjadi diakibat oleh curah hujan yang cukup tinggi. Rumpa merupakan salah satu
Desa di Kabupaten Polewali Mandar yang terdiri dari 4 dusun dengan jumlah penduduk sebanyak 29.829 jiwa dikecamatan Mapili. Desa rumpa ini berbatasan langsung dengan sungai Maloso yang merupakan salah satu sungai terbesar di Polewali Mandar. Lokasi desa yang berbatasan langsung dengan sungai mengakibatkan desa menjadi langganan banjir disaat curah hujan cukup tinggi,lokasi desa yang terdapat berdekatan di jalan raya dapat beresiko terjadinya kecelakaan lalu lintas. Hal ini dapat memicu peningkatan angka kematian di Polewali Mandar.Pengetahuan Bantuan Hidup Dasar merupakan pengetahuan awal yang dilakukan dalam tindakan pertolongan pertama dalam mempertahankan jalan nafas,dan sirkulasi (Suranadi,2017).

Kondisi kegawat daruratan dapat terjadi dimana dan kapan saja. kondisi kegawatdaruratan diantaranya adalah kecelakaan lalu lintas, serangan jantung, keracunan, tenggelam, dll (M.A and Oktaviani 2015). Berdasarkan hasil riskesdas 2007, prevalensi penyakit jantung di Indonesia sebesar 7,2\% dan merupakan lima besar penyakit tidak menular $(9,3 \%)$ dan masuk dalam 10 besar penyebab kematian pada semua tingkatan umur (Putri et al. 2019). Keadaan ini menuntut masyarakat untuk mengetahui tindakan pertolongan pertama pada korban yang ada didalam keadaan gawat darurat. Selain itu bagaimana cara menolong atau memberikan bantuan hidup dasar pada kondisi darurat henti nafas dan henti jantung. Masyarakat juga harus tahu siapa yang perlu dihubungi untuk mendapatkan pertolongan yang tepat (Wulandari 2016). Menurut WHO data kecelakaan lalu lintas 
1358 Penyuluhan Dan Pelatihan Bantuan Hidup Dasar(BHD) Kecamatan Mapili Kabupaten Polewali Mandar - Idawati Ambohamsah, Farmin Arfa, Rahmadani Tanjung

DOI: https://doi.org/10.31004/abdidas.v2i6.481

dalam dua tahun terakhir dinilai menjadi pembunuh terbesar ketiga, dibawah penyakit jantung koroner. Jika diakumulasikan dalam sehari 86 orang meninggal,dan dalam setahun sebanyak 31.185 orang meninggal (M.A and Oktaviani 2015).

Pengetahuan tentang Bantuan Hidup Dasar merupakan upaya dalam meningkatkan pengetahuan masyarakat dalam memberikan pertolongan pertama pre-hospital. Dengan diberikannya pengetahuan masyarakat dapat mengidentifikasi tanda-tanda korban ,mengetahui langkah Bantuan Hidup Dasar yang benar dan tepat,hal ini tentunya dapat mengurangi kematian.sesuai dengan hasil penelitian yang dilakukan (Dahlan, Kumaat, and Onibala 2014). Peningkatan pengetahuan Bantuan Hidup Dasar sangat diperlu dilakukan dikalangan masyarakat mengingat resiko yang ada.Pengetahuan menjadi salah satu faktor dalam kegagalan tindakan pertolongan pertama.selain itu, masyarakat awam biasanya hanya menunggu tim kesehatan tanpa memberikan sedikitpun kepada korban. Hal ini lah yang menjadi salah satu faktor keparahan kondisi korban (Anon n.d.) pelatihan merupakan upaya yang penting dilakukan dalam meningkatkan pengetahuan dan keterampilan masyarakat awam dalam tindakan pertolongan pertama (Luh et al. 2017). Selain kecepatan dalam memberikan pertolongan, ketepatan juga memiliki peran penting dalam hal ini. Banyak hal yang biasa terjadi apabila korban sudah mendapatkan pertolongan pertama namun pertolongan yang diberikan tidak tepat. Hal ini tentunya dapat memperburuk kondisi pasien, komplikasi yang dapat terjadi, pada saat melakukan kompresi pada korban seperti patah tulang dada, pneumthorax, hematothorax, luka dan memar pada paru-paru, luka pada hati dan limfa, distensi abdomen terjadi akibat peniupan yang salah dapat memperburuk kondisi korban (Suranadi 2017). Kemungkinan kondisi gawat darurat dapat terjadi pada daerah yang sulit dijangkau oleh petugas kesehatan(Dahlan et al. 2014). Kematian terjadi biasanya karena ketidak mampuan petugas kesehatan untuk menangani penderita pada fase gawatdarurat. Ketidakmampuan tersebut dapat disebabkan oleh tingkat keparahan korban, peralatan kurang memadai, belum adanya sistem yang terpadu dan pengetahuan mengenai Bantuan hidup dasar.

Penyuluhan dan pelatihan adalah salah satu upaya yang penting dilakukan untuk meningkatkan pengetahuan dan keterampilan masyarakat awam.pelatihan ini bertujuan terciptanya tenaga awam yang mampu mengenali tentang BHD (Suhartanti, Wahyu Ariyanti, and Prastya 2017). Penyuluhan dan pelatihan ini baik diberikan sejak usia untuk menciptakan generasi muda yang berkompeten dalam mengaplikasikan serta mensosialisasi cara untuk memberikan pertolongan. (Gosal Audrey Christian and Nada 2017). Penyuluhan dan pelatihan ini akan dilakukan didesa Rumpa Kecamatan Mapili.Pengabdian masyarakat ini menggunakan metode cross sectional.jumlah sampel itu sendiri merupakan 20 masyarakat di Desa Rumpa Kecamatan Mapili Kabupaten Polewali Mandar. 
1359 Penyuluhan Dan Pelatihan Bantuan Hidup Dasar(BHD) Kecamatan Mapili Kabupaten Polewali Mandar - Idawati Ambohamsah, Farmin Arfa, Rahmadani Tanjung

DOI: https://doi.org/10.31004/abdidas.v2i6.481

\section{METODE}

Metode yang digunakan adalah metode ceramah dan diskusi. Pada tahap awal dilakukan pengumpulan data masyarakat yang bersumber melalui informasi yang didapat dari Kepala Desa Rumpa dan Aparat Desa. Setelah itu tim pelaksana pengabdian masyarakat pada tanggal 29 Februari 2020 sampai dengan 05 September 2020 melakukan survey pendahuluan terkait masalah masalah yang ada pada masyarakat. Setelah mendapatkan data serta informasi terkait masyarakat yang bertempat tinggal di Desa Rumpa tim pelaksana melanjutkan membuat proposal pengabdian kepada masyarakat sesuai dengan permasalahan didapati serta ide dan masukanmasukan terkait masalah. Setelah proposal mendapatkan persetujuan selanjutnya tim pelaksana membuat penjadwalan pelaksanaan kegiatan dengan menghitung jumlah masyarakat yang bisa turut berpartisipasi dalam kegiatan tersebut. Masyarakat yang berpartisipasi dalam kegiatan ini yaitu 20 orang. Pelaksanaan pengabdian masyarakat menggunakan motode ceramah, tentang Bantuan Hidup Dasar (BHD) kepada masyakat selama 50 menit dan dilanjutkan dengan sesi diskusi. Materi pengetahuan meliputi Definisi Bantuan Hidup Dasar ,tanda dan gejala henti jantung \& napas ,cara melakukan Bantuan Hidup Dasar(BHD).

\section{HASIL DAN PEMBAHASAN}

Kegiatan pengabdian masyarakat yang dilaksanakan pada tanggal 10 September 2020 yang dilaksanakan dari pukul 09.00 s.d 12.00 WITA, bekerjasama dengan Palang Merah
Indonesia (PMI). Kegiatan ini dihadiri oleh Kepala Desa Rumpa dan Direktur AKPER YPPP WONOMULYO yang diwakili oleh Ketua LPPM AKPER YPPP WONOMULYO. Pengabdian Masyarakat "Penyuluhan dan Pelatihan Bantuan Hidup Dasar" dilaksanakan dengan tujuan untuk meningkatkan pengetahuan masyakat mengenai Bantuan Hidup Dasar(BHD) dan dapat menerapkannya dengan tepat dan cepat.kegiatan ini dihadiri oleh masyakarat sebanyak 20 orang dari sasaran yang direncanakan.

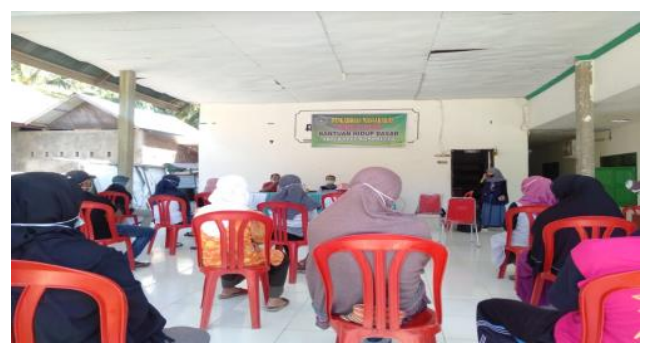

Gambar 1. Penyampaian Materi

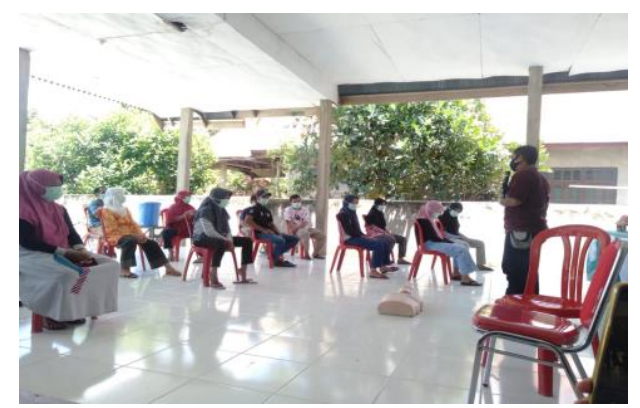

Gambar 2. Sesi Diskusi

Setelah dilakukannya penyuluhan dan pelatihan bantuan hidup dasar tercapainya target yang diharapkan yaitu :

1. Meningkatnya kesadaran masyarakat mengenai bantuan hidup dasar

2. Terjalin kerasama lintas sektoral dalam mengenai masalah gawat darurat 
1360 Penyuluhan Dan Pelatihan Bantuan Hidup Dasar(BHD) Kecamatan Mapili Kabupaten Polewali Mandar - Idawati Ambohamsah, Farmin Arfa, Rahmadani Tanjung

DOI: https://doi.org/10.31004/abdidas.v2i6.481

Berdasarkan hasil penyuluhan dan pelatihan maka didapati karakteristik peserta kegiatan pengabdian masyarakat adalah usia peserta berada antara range 20-27tahun, nilai pretest adalah $20 \%$ dan hasil nilai post test adalah $75 \%$. Terjadi peningkatan nilai rerata skor sebanyak 50 sehingga dapat disimpulkan bahwa pemberian pengetahuan dan pelatihan dapat meningkatkan pengetahuan masyakat mengenai Bantuan Hidup Dasar(BHD). Peningkatan pengetahuan diharapkan berdampak terhadap kesiapan masyarakat dalam memberikan Bantuan Hidup Dasar(BHD) kepada masyarakat saat dalam kondisi darurat.

\section{Pembahasan}

\section{PRE-TEST}

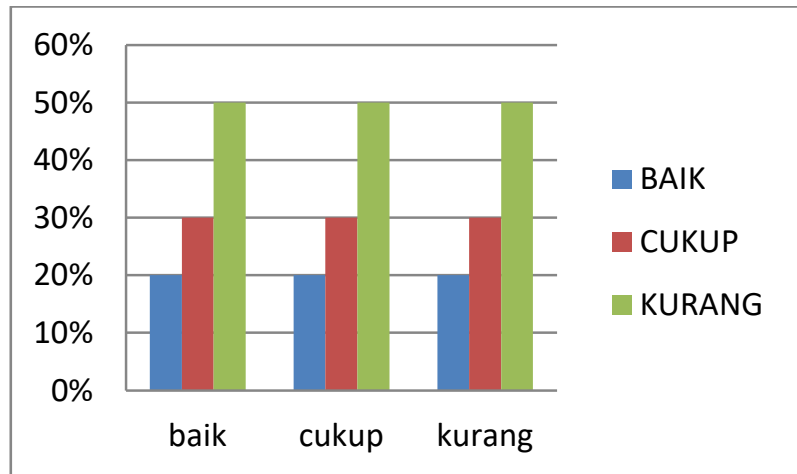

Gambar 3. Hasil Pre-test

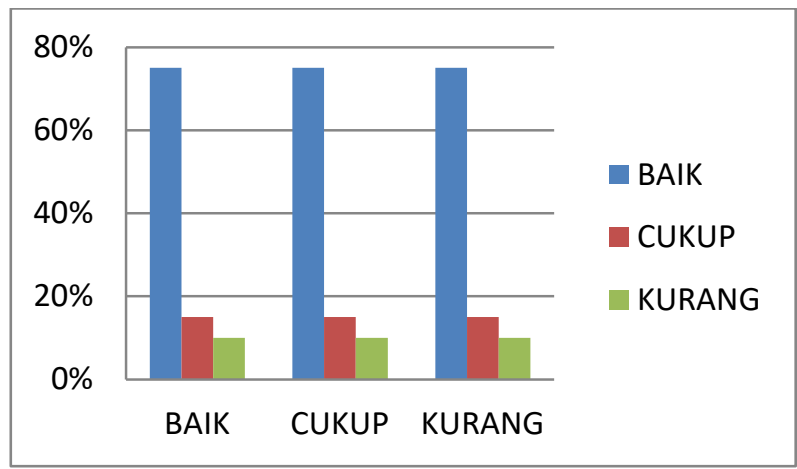

Gambar 4. Hasil Pre-test
Berdasarkan penyuluhan dan pelatihan BHD di Desa Rumpa Kecamatan Mapili didapatkan hasil Pre-Test Penyuluhan sebanyak 4 responden (20\%) dengan pengetahuan baik, dan 6 responden (30\%) dengan pengetahuan cukup dan 10 responden (50\%) dengan pengetahuan kurang. Dapat diliat dari diagram di atas skor tertinggi hasil prestest adalah $50 \%$ atau dengan kategori pengetahuan kurang. Setelah dilakukannya penyuluhan dan pelatihan didapatkan hasil posttest dengan kategori pengetahuan baik sebesar $75 \%$, kategori pengetahuan cukup 15\%, dan kategori pengetahuan kurang sebesar 10\%. Hal ini menunjukkan pengetahuan masyarakat meningkat setelah diberikan penyuluhan dan pelatihan. Kegiatan ini dilakukan dengan pemberian metode ceramah dan sesi diskusi tentang Bantuan Hidup Dasar (BHD) selama 50 menit. Materi definisi bantuan hidup dasar (BHD), tanda dan gejala korban henti jantung dan nafas, langkah-langkah melakukan BHD.

\section{SIMPULAN}

Berdasarkan hasil penyuluhan dan pelatihan maka didapati karakteristik peserta kegiatan pengabdian masyarakat adalah usia peserta berada antara range 20-27 tahun, nilai pretest adalah 20 dan hasil nilai post-test adalah 75 . Terjadi peningkatan nilai rerata skor sebanyak 50 sehingga dapat disimpulkan bahwa pemberian pengetahuan dan pelatihan dapat meningkatkan pengetahuan masyakat mengenai Bantuan Hidup Dasar (BHD). Peningkatan pengetahuan diharapkan berdampak terhadap kesiapan masyarakat dalam memberikan 
1361 Penyuluhan Dan Pelatihan Bantuan Hidup Dasar(BHD) Kecamatan Mapili Kabupaten Polewali Mandar - Idawati Ambohamsah, Farmin Arfa, Rahmadani Tanjung

DOI: https://doi.org/10.31004/abdidas.v2i6.481

Bantuan Hidup Dasar(BHD) kepada masyarakat saat dalam kondisi darurat.

\section{UCAPAN TERIMAKASIH}

Ucapan terima kasih kepada Kepala Desa di Desa Rumpa beserta aparat desa, seluruh Dosen Pembimbing Akademi Keperawatan YPPP Wonomulyo, dan teman-teman seperjuangan yang telah membantu.

\section{DAFTAR PUSTAKA}

Anon. n.d. "Capaian-2018-9079-6323104093.Pdf."

Dahlan, S., L. Kumaat, and F. Onibala. 2014. "Pengaruh Pendidikan Kesehatan Tentang Bantuan Hidup Dasar (Bhd) Terhadap Tingkat Pengetahuan Tenaga Kesehatan Di Puskesmas Wori Kecamatan Wori Kabupaten Minahasa Utara." Jurnal Keperawatan UNSRAT 2(1):110395.

Gosal Audrey Christian and I. ketut Wibawa Nada. 2017. "Bantuan Hidup Dasar." FK Udayana 20.

Luh, Ni, I. Gede Putu Darma, Nadya Treesna, I. Gusti Ayu Puja, and Made Rismwawan. 2017. "Penyuluhan Dan Pelatihan Bantuan Hidup Dasar." Jurnal Paradharma 1(2):68-74.

M.A, Rosita M. Lubis. and Suci Oktaviani. 2015. "Gambaran Tingkat Pengetahuan Perawat Di Ruang Rawat Inap Lantai 8B Rsud Koja Jakarta Tentang Bantuan Hidup Dasar (BHD)." Akademi Keperawatan Husada Karya Jaya 1(2):21-25.

Putri, Runi Pramesti, Feni Nofalia Safitri, Sahrul Munir, and Ari Hermawan Endiyono. 2019. "Pelatihan Bantuan Hidup Dasar Dengan Media Phantom Resusitasi Jantung Paru (Prejaru) Meningkatkan Pengetahuan Dan Keterampilan Bantuan Hidup Dasar Pada Orang Awam." Jurnal Gawat Darurat 1(1):7-12.

Sawiji, putra agina. 2018. "Sosialisasi Dan
Simulasi Bantuan Hidup Dasar ( BHD ) The 7 Th University Research Colloqium 2018 STIKES PKU Muhammadiyah Surakarta." The 7th University Research Colloqium 2018 Stikes PKU Muhamadiyah Surakarta 592 600.

Suhartanti, Ika, Fitria Wahyu Ariyanti, and Anndy Prastya. 2017. "Upaya Peningkatan Penguatan Chain of Survival Korban Henti Jantung Di Lua $r$ Rumah Sakit Melalui Pelatihan Bantuan Hidup Dasar Kepada Kader Kesehatan.”326-30.

Suranadi, IW. 2017. “Tingkat Pengetahuan Tentang Bantuan Hidup Dasar (Bhd) Mahasiswa Fakultas Kedokteran Universitas Udayana." Simdos.Unud.Ac.Id 2.

Wulandari, Ning Arti. 2016. "Students' Knowledge of Basic Life Support." Jurnal Ners Dan Kebidanan (Journal of Ners and Midwifery) 3(2):170-74. 